Trashing Johannesburg: Ponte City-as-Archive of Everyday Loss

\title{
Abstract:
}

Trash is rarely just trash. As cultural geography regularly insists, it is also often relational, resourceful, poetic even. It is, in short, a material of rich aesthetic and political value. But what of this relational geography is left when a space is cleaned up? What is lost? In Johannesburg, a city that has long prospered, spatially at least, through habitual cycles of rubbish and renewal, the impulse towards the sanitary has historically betrayed its tendency toward racial exclusion and erasure. As the city labours once again to clean up its self-image, I explore the everyday absence this pattern produces as well as the aesthetic interventions that this geography otherwise enables. In Mikhael Subotzky and Patrick Waterhouse's part-visual, part-textual exhibition Ponte City (2014), I locate a mode of melancholy representation that gives creative, specifically archival form to the ordinary loss imposed upon Johannesburg's tallest residential tower as part of its aborted redevelopment in 2007. In this, I attempt to reorient cultural geography's attention away from the materiality of trash, reflecting, instead, on the allied abundance of its absence.

Keywords: urban archive, melancholy, photography, Johannesburg, Ponte City

Sometime in the early 1960s, Ernest Cole captured an image of a black woman scouring the steps to a recently installed underground convenience on Von Brandis Street, Johannesburg. ${ }^{1}$ Dressed in simple overalls, she kneels on the uppermost step. To her left is a large metal can and above her head, on the entranceway, is a sign that reads in futura typeface: Slegs Blankes-Dames / Whites Only_Ladies. Small pools of rainwater on the pavement immediately adjacent suggest that the city has only recently enjoyed a heavy downpour. And, like the streets around her, the tiled steps over which she labours appear already washed clean. Indeed, only sight of fervent construction ongoing in the background intrudes on this otherwise excessively clean cityscape. But even in their state of partial completion, the sleek, vertical silhouette of the Medical Towers on what was then Jeppe Street still contribute to the city's profuse seeming claims here upon modernity: minimalist architecture, valuable public space, and rational order. Of course, the sanitised city is also the strictly segregated city, which is precisely the punctum of Cole's photograph. His image makes manifest the fundamentally racialized logic that, to follow Stephanie Newell, links spatial dirt to social 'disorder, inefficiency, and the unrecognizable'. ${ }^{2}$

Some fifty years after Cole's photograph was taken, Johannesburg now endures habitual strikes by its refuse collectors. Rubbish regularly piles up on street corners. Protests began in 2014 against the imposition of hostile management strategies proposed by PikitupJohannesburg's municipal waste management provider. Four more strikes over poor pay and working conditions were staged in 2015 and 2016, the final effort lasting some three weeks. Further protests - some legal, some not - followed a year later. The now routine sight of waste strewn across the downtown region threatens to reinscribe the reputational trashing that has blighted this part of Johannesburg since its unofficial desegregation in 1980s. ${ }^{3}$ Abandoned and left to fail by property speculators, much of the stratified centre continues to 
struggle against the disrepute that this pattern of planned disinvestment originally delivered. Admittedly, in recent years, the city has been working hard to clean up its act, repurposing key municipal infrastructure, instituting district-wide programmes of regeneration, and, lately, pledging to expropriate those residential high-rises reportedly hijacked by slum lords. Its present issues with litter, too, are more strategic than they are strictly structural. But in its effort to sanitise its self-image, the contemporary city also risks abetting, rather than correcting, the associative logic that under apartheid confused spatial sterility for social, and specifically racial, order. Eliminating the grime does not also clean up the grubby correlation that once made the aseptic constitutive of the divided city. It merely threatens to scrub out the record of racial repression dispersed amidst its historical debris.

At various moments poetic and metaphoric, at others hazardous and ungovernable, waste is, as Sarah Moore has neatly summarised, a mobile matter, traversing the cultural, affective and economic geographies of the city. ${ }^{4}$ This article takes Johannesburg's reputational as well as material trash as a point of entry into this 'parallax' geography, to cite Moore directly. ${ }^{5}$ Given the contradictions already implied, however, it is not my aim to pursue some rhetorical act of recuperation. Even as I acknowledge the general proliferation of 'garbology' as 'an activist means of consumer critique and subversion', as well as the long history of the rag-picker within the urban imagination, I am not proposing to rummage through the city's rubbish in order to recover from it some radical aesthetic value. ${ }^{6}$ For one thing, such a straightforwardly counter-discursive approach to 'rubbish art', as others wryly term it, does little to accommodate the recalcitrant, racially codified status of waste in a former colonial city like Johannesburg. ${ }^{7}$ Led, instead, by the tradition of urban photography exemplified under apartheid by Cole, my aim is to think about the transformational charge to be rescued from the city's excessive scouring, over and above its residual waste. Certainly Cole's guiding image alerts us to the ways in which dirt may prove descriptive. But his photograph does not itself elaborate upon the city's exploitative spatiality. Rather, it fixes in the 'negative'photographic as much as phenomenological - a record of the ordinary black life otherwise scrubbed out by Johannesburg's repressive, even paranoiac attachment to the sanitary. It is what has been cleaned away, not what litters the city, which is most revelatory.

If this suggests something of Johannesburg's melancholy geography, its everyday absence rather than abundance, then here I want to elaborate upon the profuse aesthetic possibilities that this geography of loss arguably also sustains. That said, this article is not principally about Cole or the apartheid city. Rather, it works through their leftovers, expanding upon the potential of this 'negative' attention in relation to the contemporary city. Elsewhere, David Eng and David Kazanjian have described how melancholy not only 'slackens and lingers' in its feeling of loss, but 'moves and creates' with it. ${ }^{8}$ And it is under precisely these deliberative as well as demiurgic terms that I turn to Mikhael Subotzky and Patrick Waterhouse's Ponte City (2014), a part-photographic, part-narrative exhibition centred upon the aborted redevelopment of the city's highest residential tower, also named Ponte City. In this, I am motivated principally by the way their published exhibition sifts through Ponte's trashed remains, producing out of them a 'negative' account of the ordinary lives thrown out as part of its renewal. This is as much about thinking differently the cycles of rubbish and 
renovation that typify Johannesburg's built environment as it is about exploring the 'alternative social promise', as Sara Ahmed has it, that loss otherwise enables. ${ }^{9}$ However, it is also about complicating in expressly melancholy terms cultural geography's more general theories of art and site. ${ }^{10}$ For while the field is rightly attentive to the co-constitution of place and practice, particularly to sites of absence and their creative remembrance, this article explores the aesthetic, specifically 'negative' archival labour that a wasteful city like Johannesburg demands. ${ }^{11}$ Without presuming to undo the tendency to make trash out of its everyday spatiality, I reflect upon the loss that precedes Ponte City's remarkably active, even hyperactive visual and textual practice, pointing to the ways in which Johannesburg's geographies of waste comprise their own immanent artistic defence.

\section{Out of the Trash Heap}

Doubtless, each city has its architectural icons, every skyline its totems. They provide a grammatical key for the city below. And as far as the trashy semiotics of Johannesburg are concerned, it is arguably the swollen, cylindrical form of the Ponte tower that typifies its more general pattern of over-accumulation, on the one hand, and waste, on the other. Completed in 1976, Ponte served originally as a prominent article in the apartheid city's desire for vertical - not just horizontal - separation, concrete shaped into a delirious, towering conceit of racial exclusivity. Indeed, dominating the skyline from its perch on the Hillbrow-Berea ridge, its 464 outward-facing apartments, set across fifty-four floors, aimed to provide the city's upwardly mobile, white middle-class with an unparalleled visual command, in all senses of the word, of the city beneath. As a segregated 'homage to the Corbusian [...] unite d'habitation', then, as Svea Josephy notes, Ponte deformed the egalitarian principles underpinning its modernist design; conceived as a city without, rather than within, the city. ${ }^{12}$ But, like the rest of downtown Johannesburg, as the hallucinations of racial capital gave way to the city's general redlining during the 1980s, Ponte was swiftly reduced to spatial garbage. For Patrick Bond, the collapse of 'consumption spectacles' like Ponte was an entirely inevitable corrective to the 'parasitical investment[s]' of the preceding decade. ${ }^{13}$ And by the time economic recession hit in 1989, Ponte's earliest residents had entirely given up on it, as had many of the commercial outlets planned for its lower floors. As a sign of its jettisoning, household rubbish discarded from those apartments on the upper floors was left to heap up in the building's hollow core. Ever since, Ponte has served as a metonym for the city's more general trashing, its internal 'pile of debris', to borrow from Walter Benjamin, a visualisation of the spatial 'catastrophe' that, for many, Johannesburg generally signifies. ${ }^{14}$

[Image 1]

To describe the building as trash, however, would also be to determine its value merely in terms of its original blueprint. Certainly, it never became the thriving, self-contained, vertical streetscape envisioned by its principal architect, Mannie Feldman. It endured, too, many of the reputed social ills that accompanied the city's more general disinvestment, with gangsterism and prostitution rumoured to have proliferated throughout. For those former white residents now generally sequestered in gated suburban communities, Ponte and its 
surrounding streets were understood to be no-go areas. But even so, by the early 1990s and the formal repeal of apartheid segregation laws, the building was again being hailed as a 'place of dreams', this time for black workers and their families as well as those most recent arrivants to Johannesburg from places like the Democratic Republic of Congo (DRC), Nigeria and Zimbabwe. ${ }^{15}$ This is not to idealize its degraded conditions. Rather, it is to emphasize the type of everyday urbanism reclaimed by the building's latest inhabitants from its delusive early impulses. It is to insist upon the unplanned, ad hoc, even unruly possibilities and everyday renewal recovered from its material as well as conceptual leftovers. ${ }^{16}$

If the extemporaneity of its everyday life served to offer a vital challenge to the city's geography of racial separation, it is perhaps by virtue of this informality that the building also found itself vulnerable before the latest pattern of creative destruction to afflict the downtown region. In this, Johannesburg is hardly alone. Even as its effects remain unevenly distributed, it is a method increasingly common to places as diverse as New York and Macau, their economically depressed centres reconditioned according to the logic of urban financialization. Under these terms, countless buildings, streets and even entire districts, first evacuated of historical meaning and ordinary cultural value, have been remade to meet the transient demands of consumer capital. Rem Koolhaas calls the result 'Junkspace', by which he means not merely 'junk in space' but, as Hal Foster elaborates, 'junk as space'. ${ }^{17}$ For Koolhaas, 'Junkspace' is not just empty of signification but is also free of the historical litter that might otherwise determine its geography. It is not a contradiction, therefore, to understand the retreat of junk as the expansion of 'Junkspace'. The result is still trash, but trash cleaned to the point of sterility and 'wrapped in a thick pack of commerce and catering'. Any trace of what was before is 'honed to irrelevant shine', leaving a series of excessively (air-)conditioned spaces, as remarkable as they are forgettable. ${ }^{18}$ Of course, in Johannesburg, it is not history in general but the very particular history of racial injustice that is being scrubbed out and forcibly forgotten.

It was with similarly sterilising ambitions in mind that an international consortium, led by local film producer David Selvan, purchased Ponte City in 2007 with plans for an, ultimately, imprudent R200 million makeover. The new owners began by removing the rubbish that had mounted into a stigma of supposed blight at the building's core. This act of symbolic sanitation was echoed socially with the subsequent eviction of many of its black residents - a mix of vulnerable migrants, young families and local students - floor-by-floor in order to make way for (an implied return of) the 'bright-minded, middle-class [...] living an avantgarde lifestyle', as Selvan put it. Fanciful plans for the building itself included a series of internal glass parapets, 'lit up in different colours so that [...] they would resemble multicoloured fireflies,' as well as a convention centre for the atrium, complete with corporate restaurants and leisure facilities designed to rival Johannesburg's proliferating suburban malls. 'It was a bold initiative and at just the right time', Selvan declared assuredly, before also admitting to the project's ruin the following year as the global financial crisis took hold. ${ }^{19}$

[Image 2] 
It was also at this point that Subotzky, a South African photographer, along with Waterhouse, a British visual artist, began to document in granular detail the everyday life of the building being tossed out by the developers. First taking photographs of trashed apartments, the pair also developed expansive renderings of the tower itself, looking both down into and up out of its striking hollow centre. Added to this are a series of more intimate shots, with portraits of some of the remaining residents interspersed amidst a general record of the building's daily comings and goings. As part of this photographic reconnaissance, the pair also began to scavenge items from the 'extraordinary array of papers', as writer Ivan Vladislavić elaborates in his own contribution to the project, 'carelessly scattered [...] among the broken furniture and abandoned possessions' of the ransacked lower flats. ${ }^{20}$ In total, Subotzky and Waterhouse spent some five years chronicling the building, accruing a remarkably thick visual ethnography of the place, which was exhibited initially as a work in progress at Cape Town's Goodman Gallery in 2010. Upon completion, Ponte City toured galleries in Paris, Antwerp, and London in 2014, and has since been made available in an elaborate printed form by specialist photobook publisher, Steidl.

Doubtless, it is impossible to cite the exhibition's decidedly global appeal without also raising concerns over its 'ideological patronage', which is to say, returning to Foster, the possible tendency of its broadly benign but also detached artists to obscure in the very name of ethnographic illumination 'the field of the other'. ${ }^{21}$ Indeed, such hesitancy over the remoteness of the aesthetic gaze is an issue that with the burgeoning of 'art-geography' has garnered increased urgency in recent decades. Critics have begun to lobby for more dialogical ways of looking that stage, for instance, a type of 'sensual proximity' with their subjects rather than claiming some direct representational authority. ${ }^{22}$ And while Ponte City retains a general sensitivity towards the everyday, if also extreme, damage that accompanied the tower's planned reduction to 'Junkspace', it is important to note that there has been no related redistribution of the cultural capital its makers doubtless secured from the exhibition itself. This is a problem compounded, in part, by the exhibition's basic design, which, as I elaborate below, prefers the interpretative over the attestable, the metaphoric over the evidential. But it is also a tragic condition of a city that regularly slips back into the logic of excess and exclusion that has, since its extractive beginnings in the nineteenth century, determined its form.

As a gateway to 'the most superfluous raw material on earth: gold', Johannesburg has long moved to reproduce its surplus capital, whether human or material, as trash, as undesirable and disposable. ${ }^{23}$ And much like the prominent slag heaps that characterise the city's low horizon, its stratified centre appears girdled by its discarded black labour. The tailings and the townships are, in their own ways, remnants of the city's essential superfluity, each rendered junk by the value expropriated from them across time. And while this pattern has splintered into a more complex geography of informality and mobility, the basic topography persists. For instance, it is not principally out of environmental concern that its toxic slag heaps are presently being depleted. Instead, it has everything to do the residual flecks of ore to be found amidst their noxious remains. And, to this extent, the aesthetic value that Ponte City attempts to recover from the building's ordinary leftovers also conspires, wittingly or otherwise, with 
the logic of exploitation and excess through which the place has long been produced. This is not to forgive its makers their hand in maintaining the city's inequities. Rather, it is to centre this discrepancy as also entirely typical of the violent contradictions that animate the trashy spatial remainders of Ponte in particular and Johannesburg at large.

\section{Ponte City-as-Archive}

To take Ponte City as symptomatic, then, of a more pervasive exploitation is to encounter a building contained, if not also wholly determined, by the rubble of its founding authority. At first sight, there seems be no escaping the basic structures and semiotic traces of Johannesburg's earliest discriminations. For instance, with obvious allusion to Cole, Subotzky and Waterhouse detail the racial prohibitions that still adorn the building's public ablutions: European Ladies / Dames, and European Gents Here. And while their legal authority may have been neutered, their visual toxicity persists. Indeed, in Subotzky and Waterhouse's rendering, these signs appear simply to have been revised by a grammar more universal, but no less noxious, than apartheid's own, namely the morphology of dirt and degradation. Even as the building seems to sanctify for its residents a provisional security beyond the racial exclusions of the past, in its state of general disrepair it also threatens to reinforce the general structure of neglect that typifies the city more generally. To this extent, Ponte's trashed status is made both the source and the seeming limit point of everyday possibility, a space of fractional vitality, on the hand, and expanding ruin, on the other. But the specific degradation that Subotzky and Waterhouse capture is also more disastrous than dirt. Selvan's attempt at cleaning up the building, by which I also mean its trashing, appears to have left its messy everyday suspended on the precipice of absolute obliteration. As such, I am interested not just in those general contradictions that structure a building like Ponte but, more purposefully, in the aesthetic, specifically archival defence that Ponte City makes against such a violently destructive process of rubbish and renewal.

Beyond Johannesburg, the city-as-archive has come to serve as a relatively common interpretation of urban space, one pursued, for instance, elsewhere in this journal by Michael Sheringham and Richard Wentworth with respect to London and Paris. ${ }^{24}$ Here, we are encouraged to envision the metropolis as a repository of historical traces - that is, as a placeholder for layer upon layer of everyday social residue. What we take as the city's legible surface is only ever constituted, to follow Sheringham, through the 'constant interaction of [its] inner and outer topographies', the creative interplay its 'archival strata'. In this way, the cityscape emerges as a product 'of accretion, juxtaposition and transformation', sharing with the formal archive not just a generic spatiality - that is, a phenomenal reality, a place within the world-but also a specific form. ${ }^{25}$ For in the irregularity of the urban environment, in its creative possibilities for disorientation and radical reorientation, and the general arbitrariness of the formal archive, each provide for the lateral associations that, in many ways, pattern archival ways of knowing more generally. And it is precisely this multiform, irregular and accretive urban structure that has for many decades serviced a type of aesthetic, archival retrieval of the city from its own seeming ruin, whether this be the ragpicker sifting through the detritus or the psychogeographer drifting through spaces forgotten from the everyday map. In other words, as Cecilie Sachs Olsen and Harriet Hawkins describe, it is the creative 
impulse that defines the city-as-archive, that locates amidst the urban trash 'poetic, often speculative, windows onto societal scale problems and processes' ${ }^{26}$

In its visual contributions to this broadly poetic tradition, Ponte City's own archival claims begin with its so-called unboxing experience. Opening up a voluminous grey cardboard container, itself reminiscent, as Josephy also notes, of 'an archival storage box', we discover a substantial, but outwardly plain, book of photography. ${ }^{27}$ The images it contains are organised principally by typology, beginning with a relatively austere series of headshots that picture some of Ponte's remaining black residents inside one of the steel-clad lifts. These unnamed portraits arguably provide a representative set of characters around whom we might focalize the increasingly abstractive photographic account of the building that follows. For instance, in the consequent series, Subotzky and Waterhouse begin with a double-page outlook taken from a window in one of the building's upper apartments. We share in the prospect of a resident, who is pictured from behind looking out across the city below. This single, comparatively indistinct view shifts and expands as it is joined on the subsequent page by three separate shots taken from other apartment windows. These photographic tiles fracture a further three times, first into sixteen, then forty-eight, and, finally, one hundred and eighty atomised images per double page. The result is a tightly stacked grid that makes to echo the vertical density of Ponte itself. Doubtless, as a motif, this gridded form implicates itself in the 'ideological associations of rationality, masculinity and modernity', to follow Lauri Firstenberg, upon which Johannesburg generally thrives. ${ }^{28}$ Here, however, its regulated order is also unsettled to accommodate the less uniform, more unruly everyday claims of Ponte's contemporary, internal disorder. Placing each of these similar but separate and partial scenes of ordinary life into such close proximity, we are encouraged to think about their mutuality, their collective narration of the place. Much like the city-as-archive's stratified way of seeing, then, the grid fosters a progressive negation of specificity in favour of the involuntary associations indulged by its juxtapositional patterning.

[Image 3]

This same reticulated form is repeated twice more in the printed exhibition, beginning with a sequence of television screens playing inside those apartments still inhabited. With these photographic images of images, Subotzky and Waterhouse appear eager to secure from the otherwise insecure migrant life of the building evidence of its everyday vitality. As 'ordinary household possessions', each TV screen arguably contains an abbreviated biography of the building's remaining residents - that is so say, following Janet Hoskins, 'a distanced form of introspection'. ${ }^{29}$ But, again, these individuated images are stacked in a uniform set of rows and columns in an effort, it seems, to secure an aggregate form for the fractured and irregular mass culture of the building. For in its everyday use, the television is also an important medium for space-binding, a technology of ordinary connectivity. ${ }^{30}$ As such, the TV and its contents function as a shared, evenly distributed constant amidst Ponte's uneven, seemingly stretched cultural landscape. Thus, when read cumulatively and comparatively as Ponte City demands, these screens provide a visual record of the building's everyday variety. Indeed, we are provided with a remarkably diverse array of scenes from local as well as international soap-operas, as well as shots from Nigerian commercials, American televangelism, and 
Nollywood film. There is even a stock image of Ponte City itself, something of a selfreferential anchor for this divergent series. In other words, the strict compositional structure imposed upon the series is precisely what enables the exhibition to contain and give archival form to something of Ponte's lived multiplicity.

Added to this account is a final series of less intrusive but no less descriptive photographs of some of the apartment front doors. Most are closed and gated, with others left open to provide a segmented view of the ordinary activity ongoing within. The metal bars that striate many of the doorways reproduce the vertical and horizontal lines that structure both Ponte's external window frames and its internal television sets. To this extent, they conclude an extended triptych of squared-off, sectional views of the building's everyday activity. And while this final sequence remains perhaps the most austere element of the three, these doorways also offer up thresholds where 'space loosens up,' as designer Quentin Stevens puts it. ${ }^{31}$ To this extent, then, the doorways are also sites of uncommon but instructive interaction between the exhibition's otherwise distant archival eye and its fragile everyday subject. For save one shot of Waterhouse - his squat figure out of focus as he takes a portrait of a resident - the artists are otherwise absent from their exhibition. However, the doorway, by distinction to the television or the window frame, arguably stages their presence, animating the ambivalence with which the pair are welcomed, or not, by those that still call Ponte home.

Collectively, these sequential ways of looking, what Subotzky and Waterhouse refer to as their 'typology of apertures', work to compress Ponte's imposing three-dimensional spatiality into a flat two-dimensionality. ${ }^{32}$ This is not to suggest that they also reduce the building's everyday complexity. Rather, their method serves to cohere its thick sociology into an equally dense, visual archival pattern. Working rapidly outwards from the specific to the general, their abstract interpretation encourages precisely the type of associational readings of urban space made by the city-as-archive more broadly, gathering up the remains of the building into a form that makes legible its plural everyday life. But, even as it works to style from its own fractional photography a sense of Ponte's residual coherence, Ponte City also contests the claims to experiential depth implied by this archival attitude to the urban sphere. For the exhibition is, above all, a response to the building's speculative trashing, an attempt to rescue its everyday from the scraps left by its botched redevelopment. Ponte, then, necessarily makes for an impoverished archival space, a formerly thriving, now ebbing repository of ordinary life. And, to this extent, any of the hyperactivity of Subotzky and Waterhouse's formal design arguably also belies the empty, evacuated remains of their subject. In its insistent serialisation, its repetitive and imbricative structures of visual display, their photographic catalogue speaks most volubly to the spatial exhaustion and everyday loss around which the place now turns.

This is a point evidenced not just by Ponte City's insistent typological attitude; even its strictly architectural photography maintains a bifocal view the building's disintegration. We might take, for instance, those striking images of the tower's hollow core, which project the robust, brutalist majesty of the place, just as the household rubbish pictured in high piles at the foot suggests the reverse. The individual apartments are presented in similarly ambivalent terms, with images of everyday habit punctured by signs of their violent defeat. Most 
compelling is a photograph of a comparatively prosaic note reminding fellow residents not to 'forget to lock the door'. As our eye drifts down from the message, we find the entire lock has been ripped away from the doorframe, any such an ordinary security utterly shattered. To this extent, the exhibition gives representation to an archive of the everyday brimming, as it were, with its own defeat. So where Sheringham insists upon the generic dynamism of the city-as-archive, in its own profuse patterns of striation, juxtaposition and transformation, Ponte City lobbies for an urban archive that might also accommodate, as part of its animated form, a more forlorn, even absent everyday record.

[Image 4]

\section{Archive of/as Loss}

As a creative, rather than strictly artefactual, way of knowing, the city-as-archive is characteristic of the conceptual redefinitions adopted by archival theory of late. But in its peculiarly melancholy enterprise, Ponte City's archival imagination also expands this practice by giving aesthetic form to the 'radical perversion' that for a theorist like Derrida defines the archive's hypermnesia more generally. By this, Derrida means to reference - after Freudthe 'diabolical death drive, [...] a drive, thus, of loss' that constitutes the archive. Developing a sense of the archive's internal psychopathologies, he reflects on the way in which it potentially works 'to devour [itself] even before producing [itself] on the outside'. ${ }^{33}$ As far as this article is concerned, however, the archive's self-destructive drive is central not so much in unsettling its evidential authority but, as literary critic Jonathan Boulter puts it, in reconceiving it as a 'topos' of loss. ${ }^{34}$ Certainly, I accept the strategic acts of dislocation and epistemic disorientation performed by the archive as part of its discursive, and often also imperial, authority. But more pertinent here is the way the archive produces itself as a space of spectrality, conditioned, that is, by an identification with its own absent traces, its own 'impossible archaeology,' as Derrida also has it. ${ }^{35}$ Indeed, in more speculative terms, the melancholy structure that defines this identification is arguably also what incorporates the archive, psychoanalytically speaking at least. This is, in part, how Freud also understands the ego and its melancholy formation - as an internalisation of a loss that cannot be mourned and let go. To follow Judith Butler: 'identifications formed from an unfinished grief are [...] phantasmatically preserved in and as the ego'. ${ }^{36}$ To extrapolate this psychoanalytical claim, then, I want to suggest a melancholy interpretation of the archive that begins with its sublimation —or, better, its spatialisation —of loss.

As a condition of this melancholy archival praxis, it is precisely the everyday artefacts absented from Ponte City-as-archive that are most revelatory. Like Cole's photograph of the sanitised apartheid city, it is those ordinary lives that have been erased from the record that here sustain our attention. For Claire M. Chambers, such a negative attention is altogether exemplary of the archive's 'apophatic form'. Challenging its presumed logic of excess, its seeming tendency to preserve 'more than is necessary', this apophatic account is, Chambers insists, the archive's way of 'knowing through what cannot be known', its narration of what cannot be read. ${ }^{37}$ This negative epistemology is instructive, firstly, in reorienting our understanding of the urban archive's typically accretive structure. This is by no means to 
undo its imaginative and expressive impulses, as set out by Sachs Olsen and Hawkins. Indeed, to think more abstractly about the restless compositional form around which Ponte City-as-archive turns, this melancholy method is also a potential explanation for the exhibition's profuse creativity and, perhaps, the poeticism of the city-as-archive more generally. For as Freud has it, in its attachment to loss, melancholy 'behaves like an open wound, drawing to itself cathectic energy from all sides'. ${ }^{38}$ Unable to let go, it attempts to console itself, as Fred Moten elsewhere elaborates, with a 'magnification or intensification of the [lost] object', prospering amidst an 'abundance of the negative'. ${ }^{39}$ Under melancholy eyes, then, loss ceases to be just about lack; it is also about profusion, a profusion that works as a 'provocation to create'- to follow Anne Cvetkovich. ${ }^{40}$ In other words, melancholy is also a partially generative, transformational affect. And it is precisely under these creative, demiurgic terms that I understand the restless representational vitality that motivates Ponte City, a restlessness that produces, as much as it 'taps', this archive of loss. ${ }^{41}$

In an effort to elaborate upon Ponte City's melancholy incorporation of its archival subject, I have so far restricted my analysis to the exhibition's visual display. ${ }^{42}$ But the narrative accounts of Ponte commissioned by Subotzky and Waterhouse from some of Johannesburg's most reputable biographers, including Lindsay Bremner, Harry Kalmer and Kgebetli Moele, make their own vital contribution this archive of loss - and not just by way of their content. In the first instance, these creative-critical texts are each included separately in one of seventeen individual pamphlets. The pamphlets are themselves housed in a smaller compartment of the boxed exhibition, only discoverable once the photographic catalogue has been extracted. And interspersed amidst their narrative interpretations of the building are additional facsimiles of some of the many scraps of newspaper reports, personal photographs, bills, shopping lists and even love letters recovered by Subotzky and Waterhouse from Ponte's abandoned apartments. In their juxtaposition, then, this ordinary ephemera is made to complement the exhibition's own textuality, while the commissioned narrative accounts are, likewise, produced as a found material of sorts, seemingly uncovered amidst Ponte's general leftovers.

As a formal feature of Ponte City's visual archive, however, these pamphlets are more than merely supplementary. Rather, they function primarily as graphic inserts, each jacketed by segments of photographs hewn from the principle exhibition. The photographic catalogue bears its own witness to this excision, with a central rectangular fragment, into which each these pamphlets precisely fit, removed from seventeen of the otherwise regular double-page images. As if such a formal arrangement were itself not sufficiently instructive, these intermittent visual scars in the catalogue also operate as palimpsests, revealing partial copies of the found letters and personal photographs included elsewhere in the project. To this extent, then, the published exhibition works actively - even obsessively - to stage the material lapses that also constitute Ponte's everyday geography, prompting us, too, to read back into its own extant gaps. This is not to redeem these spaces, but to insist upon the imaginative possibilities that emerge from this site of profuse loss. For in its intricate layering and co-mixing of text and image, Ponte City makes persistent interpretive demands. Most obviously, in reconstituting the catalogue and returning each pamphlet to its parent 
photograph, we are encouraged to approach the respective narratives they contain both in the context of their photographic frames and against the ordinary objet trouvé they now conceal. As part of this archival method, each element is potentially transformed by its interaction with, and obstruction of, the rest of its constituent parts. Indeed, returning the inserts to their appropriate section, their narrative accounts potentially serve to ratify the published catalogue.

[Image 5]

As an instructive example, in his contribution to pamphlet \#VIII, entitled 'Flat 3607', Ivan Vladislavić, a prolific contemporary chronicler of the city, reflects on the textual ephemera that Subotzky and Waterhouse reputedly gathered up from a single apartment. The pamphlet has as its cover an extract from a blurred, oversaturated and sun-damaged photograph of some three-dozen black men aboard a ship. We are invited, it seems, to imagine the narrative contents of the pamphlet as an elaboration of the figurally and actually obscured lives captured on the cover, a kind of archival explanation of the photograph's own descriptive elisions. Here, the textual fragments around which Vladislavić chooses to construct his narrative are partially evidentiary. 'This paper trail shows that there were at least two people living in [the flat]: Jerome Matondo Kabangu and Promise Ilunga Kinkela', claims Vladislavić, before beginning a cautious biographical account assembled from the remnants of official and personal correspondence:

Kabangu was born in the [DRC] in 1981 and grew up on the shores of Lake Tanganyika. As he tells it, his life was disrupted by war in the late 1990s, with the murder of his father and the persecution of his family. [...] To avoid being forced into the army, he joined up with some cousins, including Kinkela, and fled the country. They went from Manono to Pweto, and then across the border into Zambia [...]. After ten days, they crossed into Zimbabwe and went straight into South Africa, entering the country illegally in April 2003. ${ }^{43}$

Working from the 'fragmentary and uncertain' biographical traces scattered amidst variously discarded application forms, this summary remains insistent in its instability. For one thing, it contends with the multiple slippages and inconsistencies typical of 'people desperate', as Vladislavić puts it, 'to prove that they are deserving of refugee status or humanitarian assistance'. ${ }^{44}$ Names morph and biographical details shift depending on the presumed reader. As a result, qualifiers like 'seems' and 'perhaps' proliferate throughout Vladislavić's account, each a linguistic reminder of the lived insecurity from which his text emerges.

As a work of deduction, rather than certification, then, this non-fictional account of Flat 3607 also serves as an extension to the archival attention that Vladislavić applies to Johannesburg elsewhere in his writing. Take, for instance, Portrait with Keys (2006): indexed and classified, its loosely fictionalised sorties through Johannesburg are arranged in terms that produce out of the city's relative incoherence a supposedly systematised order, a method of associative interpretation that responds to, without overwriting, the experiential disorder of the space. Peter Beilharz and Sian Supski describe the text as almost 'photographic' in its 'sociological impressionism' of the city. ${ }^{45}$ Although much briefer, his contribution to Ponte City works similarly as a gestural snapshot of this single orphaned flat. Rather than 
compensating for the blurred reality of its cover art, 'Flat 3607' insists upon the experiential turmoil that likely yielded this type of image to begin with. In this way, his essay exploits the lateral patterns of accretion and collocation defining Ponte City-as-archive more broadly. But here text and image also abet the provisory status of the other, each refusing to overcome or diminish the basic loss of ordinary history that now defines the building.

In this brief but exemplary lesson in reading the visual with the verbal, 'Flat 3607' establishes something of the intertextual methodology adopted by Ponte City more generally in order to contain, rather than fix and make inert, the building's fugitive everyday. It is a necessarily challenging, almost impossible task. Indeed, at their most unruly, Ponte City's narrative pamphlets threaten to collapse altogether the fragile coherence that might otherwise be extracted from the photographic catalogue's strict compositional design. For one thing, there is little to deter us from reading each text out of its implied context - that is, from feeding their narratives arbitrarily back into the visual catalogue. After all, the pamphlets are not embedded within the photographs but float across their surface. And while we may choose to indulge the associations made possible by this mobile arrangement, equally, there is no reason to insist upon their inclusion in the exhibition's general exegesis. Detached from the catalogue, these commissioned texts threaten to escape altogether from the archive, their narrative contents disappearing from view, much like the everyday life of the building itself. Indeed, the palimpsestic catalogue is arguably just as revelatory in its scarred form, its lacerated photographs testament to Ponte's extant everyday disfigurement. Amidst the solidity of its concrete architecture, then, the building is made to contain a series unstable, even errant archival possibilities.

But if are we are to accept the relative indeterminacy that conditions Ponte City-as-archive, we must also acknowledge the ways in which it is above all an immanent account of the loss imposed upon the building - that is, a formal, volatile reiteration of the ordinary violence sustained by its abortive renewal. Dennis Hirson puts it well in his contribution to pamphlet \#XVII when he describes Ponte City as 'a conversation between composition and chaos, between chosen artistic form on the one hand, raw-edged witnessing on the other' ${ }^{46}$ Elaborating upon this incongruous, even impossible everyday empiricism, he draws instructive precedence from the experimental urban inventories of Georges Perec. For like Ponte City, Perec's Life: A User's Manual takes as its object of analysis the messy, often incoherent everyday contained by a single apartment block, a space best imagined, Perec claims in suitably agglomerative terms, as a 'jigsaw puzzle'. It is, he claims:

[A] pattern, that is to say a form, a structure: the element's existence does not precede the existence of the whole, it comes neither before nor after it, for the parts do not determine the pattern, but the pattern determines the parts. ${ }^{47}$

His summary serves as a useful account of the abstract patterning that Subotzky and Waterhouse, too, pursue in their representational account of Ponte. But, crucially, unlike the jigsaw, the layered, juxtapositional structure favoured by Ponte City-as-archive proves descriptive in its state of partial completion. It does not require the justification of the final 
image to endorse its archival interpretation of the building's 'endotic' life. ${ }^{48}$ Rather, to rework to Perec's guiding metaphor, it is the missing pieces that count.

\section{Conclusion: 'Afterimages'}

As an attempt to secure an archival form for the evacuated everyday remains of Ponte, the melancholy method favoured by Subotzky and Waterhouse is a difficult one to condense. In its restless, almost manic activity, the exhibition regularly spills out beyond the boundaries of neat description. It also demands an uncommon attention to an ordinary sphere that lies beyond the frame and off the page. To take pamphlet \#VII, 'Afterimages', as a potential summary of the 'negative' attention that Ponte City performs, then, must be to understand it as typical and not. Comprised exclusively of photography, both found and original, it forgoes the textual imbrications favoured in other moments. But in its grafting of discarded personal snapshots over formal photographs of the self-same abandoned apartments from which they were reclaimed, the series also brings us closest to the transformational effects of the exhibition's more general melancholy way of looking. Each of these personal photos, featuring former residents in altogether ordinary acts of reading, embracing, or conversing, is quotidian to the point of trivial. Envisioned in this layered form, however, they are utterly transformed by the empty, lifeless interiors that now frame them. They indulge little of their benign sentimentalism, refracting, instead, the violent loss that now conditions the place around them. And, in this, the pamphlet makes for a voided archival artefact, an evocative record of an ordinary life pervaded by its own contemporary absence.

[Image 6]

Foster has elsewhere described the archive as 'sometimes melancholy, often vertiginous, always incomplete' ${ }^{49}$ Composed of, not from, memory, of memory lost, to return to Chambers, I have tried to suggest how Ponte City-as-archive offers up an aesthetic form for this partiality. But in its negative abundance, the exhibition also expresses, I aver, the 'creative possibility' that flows from the city's general geographies of waste, insisting upon the aesthetic imperatives that flourish amidst Johannesburg's regularly trashed everyday terrain. ${ }^{50}$ I have made this claim not to redeem the pattern of racial exploitation and exclusion that, ultimately, defines the city. Rather, my ambition here has been to expand upon the 'condition of possibility', to follow Moten, that loss also contains. ${ }^{51}$ In its melancholy labour, Ponte City works insistently to disrupt our geographical imagination. Absence is made generative but not recuperative; its irredeemable status here an indictment on the unjust, trashy logic that rules the city at large. In this, Johannesburg is arguably extreme. But it is also indicative of the threat that the proliferation of junk-as-space poses to ordinary, specifically black life in the postcolonial urban sphere. And even while Ponte City remains an inadequate rejoinder, it succeeds in alerting us to the poetic defence that the geography of waste enables, perhaps even despite itself.

\footnotetext{
${ }^{1}$ Like a good number of Cole's photographs, this one is uncaptioned.
} 
${ }^{2}$ Stephanie Newell, 'Dirty Familiars: Colonial Encounters in African Cities', in Christoph Linder and Miriam Meissner, eds, Global Garbage: Urban Imaginaries of Waste, Excess, and Abandonment (London: Routledge, 2016), p. 40.

${ }^{3}$ For more on Johannesburg's waste-management infrastructure, see Sarah Charlton, 'Waste Pickers/Informal Recyclers,' in Changing Space, Changing City: Johannesburg After Apartheid (Johannesburg: Wits University Press, 2014), pp.539-545.

${ }^{4}$ See Sarah A. Moore, 'Garbage Matters: Concepts in New Geographies of Waste', Progress in Human Geography, XXXVI (2012), PP. 780-799.

${ }^{5}$ Moore, 'Garbage Matters', p.781.

${ }^{6}$ Christoph Lindner and Miriam Meissner, 'Globalization, Garbage, and the Urban Environment', in Global Garbage, p. 10.

${ }^{7}$ For a pertinent elaboration of 'rubbish art,' see Harriet Hawkins, 'Turn Your Trash into... Rubbish, Art and Politics. Richard Wentworth's Geographical Imagination,' Social and Cultural Geography XI (2010), pp. 805827.

${ }^{8}$ David Eng and David Kazanjian, 'Introduction: Mourning Remains', in David Eng and David Kazanjian, eds, Loss: The Politics of Mourning (Berkley, CA: University of California Press, 2003), p. 2.

${ }^{9}$ Sara Ahmed, 'Multiculturalism and the Pursuit of Happiness', New Directions LXIII (2007/2008), p. 135.

${ }^{10}$ For a review of art practice and spatial analysis, see Harriet Hawkins, 'Geography and Art. An Expanding

Field: Site, the Body and Practice,' Progress in Human Geography, XXXVII (2012), pp. 52-71.

${ }^{11}$ See, for example, Lars Meier, Lars Frers and Erika Sigvardsdotter, 'The Importance of Absence in the Present: Practices of Remembrance and Contestation of Absence', cultural geographies, XX (2013), pp. 423440.

12 Svea Josephy, 'Acropolis Now: Ponte City as "Portrait of a City", Thesis Eleven CXLI (2017), p. 76.

${ }^{13}$ Patrick Bond, Cities of Gold, Townships of Coal: Essay on South Africa's New Urban Crisis (Trenton, NJ: Africa World Press, 2000), p. 19.

${ }^{14}$ Walter Benjamin, Illuminations: Essays and Reflections (New York: Schocken Boks, 2007), pp. 57-8.

15 'I: Newsreel' in Mikhael Subotzky and Patrick Waterhouse, Ponte City (Gottingen: Steindl Verlag, 2014), n.p.

${ }^{16}$ See John Chase, Margaret Crawford and John Kaliski, Everyday Urbanism (New York: Monacelli Press, 1999).

${ }^{17}$ Hal Foster, 'Running Room', in Rem Koolhaas, Junk Space with Running Room (London: Notting Hill

Editions, 2013), p. 48. Emphasis original.

${ }^{18}$ Rem Koolhaas, 'Junkspace', in Junk Space, p. 20.

${ }^{19}$ David Selvan,'V: Live Your Life', in Ponte City, pp. 13-14.

${ }^{20}$ Ivan Vladislavić, 'VIII: Flat 3607', in Ponte City, p. 3.

${ }^{21}$ Hal Foster, The Return of the Real: The Avant-Garde at the End of the Century (Cambridge, MA: MIT Pres, 1996), pp. 172-3.

${ }^{22}$ Kris Rutten, An van. Dienderen and Ronald Soetaert, 'Revising the Ethnographic Turn in Contemporary Art', Critical Arts XXVII (2013), p. 468. For a geographical account, see Kate Foster and Hayden Lorimer, 'Cultural Geography as Practice: Some Reflections on Art-Geography as Collaboration', cultural geography XIV (2007), pp. 425-432.

${ }_{23}$ Achille Mbembe, 'Aesthetics of Superfluity', in Sarah Nuttall and Achille Mbembe, eds, Johannesburg: The Elusive Metropolis (Durham, NC: Duke University Press, 2008), pp. 41-2.

${ }^{24}$ See Michael Sheringham and Richard Wentworth, 'City as Archive: a Dialogue between Theory and Practice,' cultural geographies XXIII (2016), pp. 517-523.

${ }^{25}$ Michael Sheringham, 'Archiving', in Matthew Beaumont and Gregory Dart, eds, Restless Cities (London: Verso, 2010), p. 9.

${ }^{26}$ Cecilie Sachs Olsen and Harriet Hawkins, 'Archiving an Urban Exploration: MR NICE GUY, cooking oil drums, sterile blister packs and uncanny bikinis', cultural geographies, XXIII (2016), p. 542.

${ }^{27}$ Josephy, 'Acropolis Now', p. 20.

${ }^{28}$ Lauri Firstenberg, 'Representing the Body Archivally in South African Photography', Art Journal LX1 (2002), p. 65.

${ }^{29}$ Janet Hoskins, Biographical Objects: How Things Tell the Story of People's Lives (New York: Routledge, 1998), p. 2.

${ }^{30}$ See Anna McCarthy, Ambient Television: Visual Culture and Public Space (Durham, NC: Duke University Press, 2001), pp. 14-15.

${ }^{31}$ Quentin Stevens, 'Betwixt and Between: Building Thresholds, Liminality and Public Space', in Karen A. Franck and Quentin Stevens, eds., Loose Space: Possibility and Diversity in Urban Life (New York: Routledge, 2006), pp. 73-4. 


\footnotetext{
${ }^{32}$ Subotzky and Waterhouse, Ponte City, n.p.

${ }^{33}$ Jacques Derrida, Archive Fever: a Freudian Impression (Chicago, IL: University of Chicago Press, 1996), pp.13-14.

${ }^{34}$ Jonathan Boulter, Melancholy and the Archive: Trauma, History and Memory in the Contemporary Novel (London: Continuum, 2011), p. 1.

${ }^{35}$ Derrida, Archive Fever, p. 54.

${ }^{36}$ Judith Butler, The Psychic Life of Power: Theories in Subjection (Stanford, CA: Stanford University Press, 1997), p. 132.

${ }^{37}$ Claire M. Chambers, Performance Studies and Negative Epistemology: Performance Apophatics

(Basingstoke: Palgrave Macmillan, 2017), pp. 131-2, 143.

${ }^{38}$ Sigmund Freud, 'Mourning and Melancholia', The Complete Works of Sigmund Fred, Vol. XIV (London: Hogarth Press, 1917), p. 163.

${ }^{39}$ Fred Moten, 'Black Mo'nin', in Loss: The Politics of Mourning, pp. 64-65.

${ }^{40}$ Ann Cvetkovich, 'Legacies of Trauma, Legacies of Activism: ACT UP's Lesbians', in Loss: The Politics of Mourning, p. 453.

${ }^{41}$ For more on the performative production of the urban archive, see Katie Beswick, Harriet Hawkins and Joseph Kohlmaier, 'The Road to Epidaurus is like the road to creation: tapping the urban archive,' cultural geographies, XXIII, (2016), pp. 545-552.

${ }^{42}$ For more on melancholy and photography, see Jay Prosser, Light in the Dark Room: Photography and Loss (Minneapolis: University of Minnesota Press, 2004).

${ }^{43}$ Ivan Vladislavić, 'VIII: Flat 3607', Ponte City, p. 3. The names of the residents have been changed, Vladislavić confirms in an endnote.

${ }^{44}$ Vladislavić, 'Flat 3607 ', p. 5.

${ }^{45}$ Peter Beilharz and Sian Supski, 'Finding Ivan Vladislavić-Writing the City', Thesis Eleven CXXXVI (2016), p. 16. Readers of Vladislavić will be aware of the many ways in which the photographic eye is thematised in his writing, most prominently in his novel Double Negative (2010).

${ }^{46}$ Dennis Hirson, 'XVII: Perec/Ponte', Ponte City, pp. 5-6.

${ }^{47}$ Georges Perec, Life, a User's Manual (London: Harvill, 1996), p.1.

${ }^{48}$ Georges Perec, 'Approaches to What?', in The Everyday Life Reader, p. 177.

${ }^{49}$ Hal Foster, 'An Archival Impulse', October CX (2004), p. 12.

${ }^{50}$ Chambers, Negative Epistemology, p. 132.

${ }^{51}$ Fred Moten, 'Black Mo'nin', p. 62.
} 